UDC 577.352:544.015.4:547.426

\title{
Effects of oxyethylated glycerol cryoprotectants on phase transitions of DPPC model membranes
}

\author{
N. A. Kasian ${ }^{1}$, A. O. Krasnikova ${ }^{1}$, O. V. Vashchenko ${ }^{1}$, L. N. Lisetski ${ }^{1}$, \\ A. V. Zinchenko ${ }^{2}$, A. M. Kompaniets ${ }^{2}$, M. V. Ratushna ${ }^{3}$ \\ ${ }^{1}$ Institute for Scintillation Materials, NAS of Ukraine \\ 60, Lenin Ave., Kharkiv, Ukraine, 61001 \\ ${ }^{2}$ Institute for Problems of Cryobiology and Cryomedicine, NAS of Ukraine \\ 23, Pereyaslovska Str., Kharkiv, Ukraine, 61015 \\ ${ }^{3}$ Institute of Neurology, Psychiatry and Narcology, NAMS of Ukraine \\ 46, Akademika Pavlova Str., Kharkiv, Ukraine, 61068 \\ kasian@isma.kharkov.ua
}

\begin{abstract}
Aim. To determine the effect of the oxyethylated glycerol cryoprotectants $\left(\mathrm{OEG}_{\mathrm{n}}\right)$ with polymerization degrees $n=5,25,30$ on the phase states and phase transitions of dipalmitoylphosphatidylcholine (DPPC)based model membranes. Methods. Differential scanning calorimetry. Results. Model lipid membranes on water/OEG $\mathrm{n}_{\mathrm{n}}$ and water/glycerol subphases with varying cryoprotectant concentrations from 0 to $\sim 100 \%$ $\mathrm{w} / \mathrm{w}$ were studied. A significant raise in the pre-transition and main phase transition temperatures with increasing $\mathrm{OEG}_{\mathrm{n}}$ concentration was noted whereas the membrane melting peak persist to $100 \% \mathrm{w} / \mathrm{w} \mathrm{OEG}_{\mathrm{n}}$. A sharp increase in the melting enthalpy was observed for $\mathrm{OEG}_{\mathrm{n}=5}$. Conclusions. The solvating ability of the subphase in DPPC membranes decreases in the order water $>$ glycerol $>\mathrm{OEG}_{\mathrm{n}=5}>\mathrm{OEG}_{\mathrm{n}=25}>\mathrm{OEG}_{\mathrm{n}=30}$, which correlates with the relative number of groups effectively contributing to the solvation process.
\end{abstract}

Ke y w or d s: model lipid membranes, oxyethylated glycerol cryoprotectants, phase transitions, solvation.

\section{Introduction}

Most of biologically relevant substances can modify the structure and functioning of biomembranes, in particular, by their interaction with lipid bilayers [1-3]. Cryoprotectants, which are used for suppression of the ice formation in cells upon freezing, could also be expected to have a marked membranotropic activity, both directly and by water-mediated mechanisms. At a high concentration of cryoprotectants, significant effects on the structure and barrier properties of biomembranes were noted, as well as inhibition of the membrane protein activity [4-6]. Therefore, clarification of the mechanisms of cryoprotectant action at the cellular and sub-cellular levels is an important problem of modern biophysics. A standard approach in studies of the membranotropic action is the use of model lipid membranes, in particular, of phospholipid water dispersions in the form of liposomes or lamellar structures $[1,2]$.

Many aspects of the membranotropic action have been extensively studied for «traditional» cryoprotectants like glycerol and dimethylsulfoxide (DMSO). It is generally accepted that DMSO tends to be localized in the membrane close to carbonyl, glycerol and adjacent methylene groups [7]. Depending on the concentration, DMSO can lead to lateral extension of the membrane, a decrease of its thickness and increase of penetrability, up to eventual disintegration of the lipid bilayer [7-9]. As a membranotropic agent

(C) 2015 N. A. Kasian et al.; Published by the Institute of Molecular Biology and Genetics, NAS of Ukraine on behalf of Biopolymers and Cell. This is an Open Access article distributed under the terms of the Creative Commons Attribution License (http://creativecommons.org/licenses/by/4.0/), which permits unrestricted reuse, distribution, and reproduction in any medium, provided the original work is properly cited 
(MTA), DMSO substantially increases the melting (main phase transition) temperature $T_{m}$ of the lipid membranes based on hydrated dipalmitoylphosphatidylcholine (DPPC) [10].

As compared with DMSO, hydrophilic properties of glycerol are more pronounced, with its partition coefficient in the «n-octanol - water» system being equal to 0.005 ( $\sim .25$ for DMSO), which explains a weaker penetration of glycerol through the cell membrane [11]. The literature data of the membranotropic activity of glycerol are rather contradictory. According to $[6,12,13]$, glycerol is localized in the region of polar groups, affecting the thickness of the phospholipid membrane and inter-membrane layer of the solvent. Another opinion is that glycerol does not penetrate to the region of polar groups of the bilayer and does not affect the membrane thickness, and its interaction with water is stronger than that with the lipid polar groups [14]. It has been shown [15] that temperatures and enthalpies of phase transitions of phospholipid liposomes are not affected substantially when glycerol substitutes for water, and liposomes of basically the same structure can exist with subphases of water, glycerol or ethylene glycol [12].

Such a remarkable property (the ability to replace water in conditions of membrane dehydration without effects on the lamellar organization of lipids and their transition from the liquid crystalline to the gel phase) has been also noted for disaccharides and urea [15-19]. Thus, trehalose decreases the melting temperature $T_{m}$ of dry DPPC even stronger than water, also increasing the enthalpy of this phase transition [19]. This effect is assumed to have an important biophysical significance. Lowering of the membrane melting temperature in the dehydration conditions preserves its liquid crystalline phase state. As a result, many undesirable processes commonly noted at the transition from liquid crystalline to gel phase are suppressed, e.g. the phase separation of lipids or aggregation of membrane proteins [16-19].

An important aspect of the membranotropic action of many cryoprotectants (methanol, ethanol, ethylene glycol, glycerol) is the formation of the interdigitated gel phase $L_{\beta I}$, when hydrocarbon «tails» of lipids penetrate (fully or partially) into the adja- cent layer $[12,20-22]$. The liquid crystalline $L_{a}$-phase is preserved, whereas the intermediate phase $P_{\beta}$, disappears $[12,21,22]$. Along with the X-ray structural data, the formation of the interdigitated phase is reflected also in the increased membrane melting enthalpy [22], intensity changes in the Raman bands of methylene groups [23], etc.

Thus, most of the cryoprotectants show the pronounced membranotropic action due to the direct interactions with the polar region of the lipid membrane and strong interaction with water $[6,24,25]$. Therefore, further studies of the membranotropic action of cryoprotectants and clarification of its mechanism are very important for the development of new cryoprotectant media and within the framework of the general problem of membrane interaction with guest compounds.

One of the promising methods for the synthesis of new cryoprotectants is oxyethylation. Thus, by oxyethylation of glycerol a homologous series of compounds could be obtained with very similar properties but different molecular mass. Such substances oxyethylated glycerol derivatives with different degree of polymerization $n\left(\mathrm{OEG}_{\mathrm{n}}\right)$ [26-29] - to our knowledge, have never been studied from the viewpoint of their membranotropic effect. In our work, we studied the phase transitions of DPPC model membranes using water/OEG $(n=5,25$ and 30$)$ mixtures as a subphase. In the subphases, water was gradually replaced by the cryoprotectant in continuous series of the water/OEG $\mathrm{O}_{\mathrm{n}}$ ratios. For comparison, control experiments in the identical conditions were carried out for DPPC membranes with water/glycerol mixtures as a subphase (as noted above, the membranotropic properties of glycerol could be considered as sufficiently well studied).

\section{Materials and Methods}

\section{Materials}

Oxyethylated glycerol cryoprotectants with polymerizatiom degrees 5, 25 and $30\left(\mathrm{OEG}_{\mathrm{n}=5}, \mathrm{OEG}_{\mathrm{n}=25}\right.$, $\mathrm{OEG}_{\mathrm{n}=30}$ ) were synthesized at Barva chemical plant (Ukraine) by the technology developed at the Institute for Problems of Cryobiology and Cryomedicine 


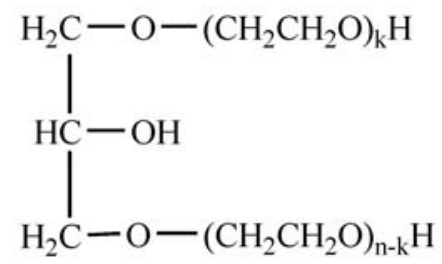

Fig. 1. Chemical structure of $\mathrm{OEG}_{\mathrm{n}}, \mathrm{k}<\mathrm{n}$

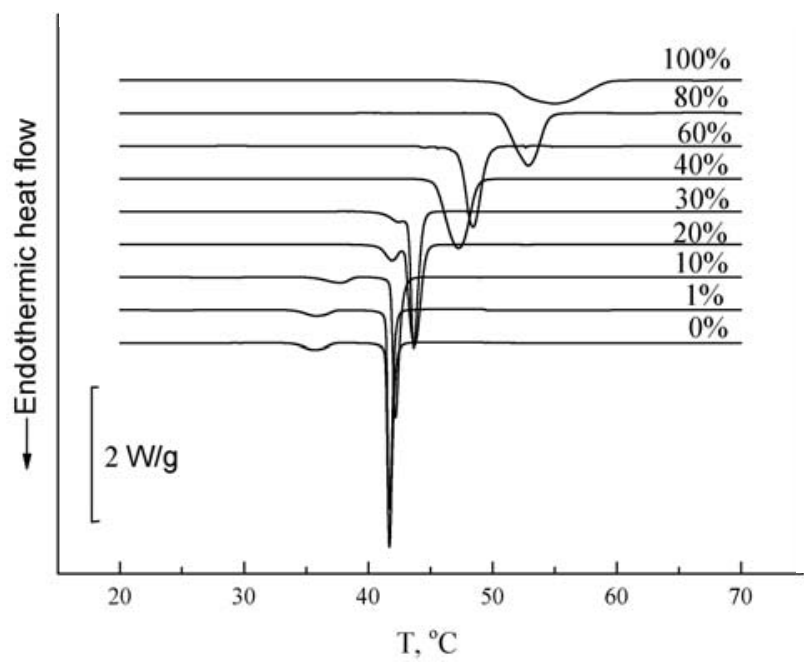

Fig. 2. $\mathrm{DSC}$ thermograms of DPPC membranes on water/OEG $\mathrm{O}_{\mathrm{n}=5}$ subphase in the heating mode for samples with different mass concentration of $\mathrm{OEG}_{\mathrm{n}=5}$ in the subphase

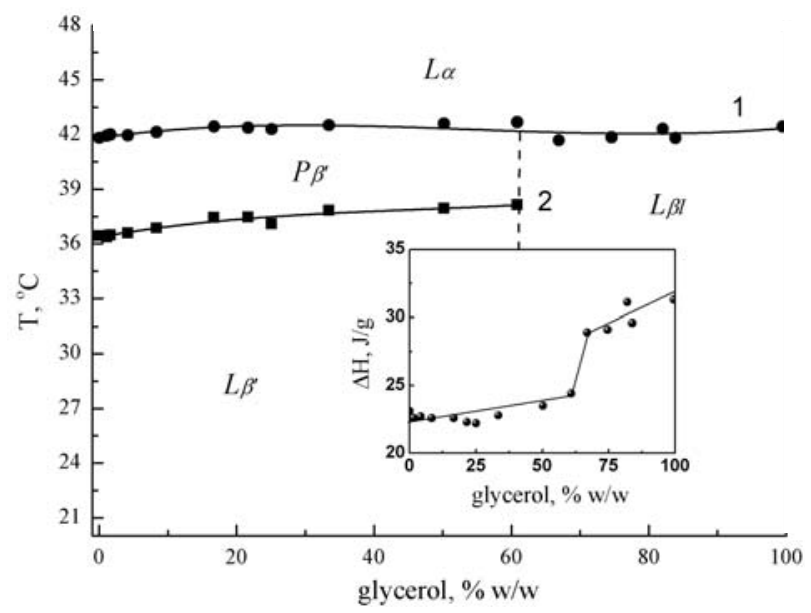

Fig. 3. Phase diagram of DPPC membranes on water/glycerol subphases with different glycerol content: 1 - melting temperature $T_{m}, 2$ - pre-transition temperature $T_{p}$. Insert shows the melting enthalpy. Designations of phases are the same as given in the text
[29], where they were additionally purified. The chemical structure of OEGs is shown in Fig. 1. DPPC (Avanti Polar Lipids, USA) was used for preparation of model membranes in the form of multilamellar dispersions on the water/cryoprotectant subphases.

\section{Model lipid membrane preparation}

DPPC multilamellar dispersions were obtained by lipid hydration $(1: 3 \mathrm{w} / \mathrm{w})$ and incubation at room temperature for 7-8 days with periodical heating up to $\sim 50{ }^{\circ} \mathrm{C}$ and intensive stirring [30]. Comparison of the pre-transition $\left(T_{p}\right)$ and main phase transition $\left(T_{m}\right)$ temperatures with the literature data $[30,31]$ was used for control of the model membrane quality. Binary DPPC+water systems with water content from $0 \%$ to $97 \% \mathrm{w} / \mathrm{w}$, as well as DPPC multilamellar dispersions on the water/OEG ${ }_{n}$ and water/glycerol subphase (ternary systems $\mathrm{DPPC}+\left[\right.$ water/ $\left./ \mathrm{OEG}_{\mathrm{n}}\right]$ and $\mathrm{DPPC}+[$ water/glycerol]) were obtained in the similar way. The subphase composition was varied from $100 \%$ water to $\sim 100 \%$ cryoprotectant.

\section{Differential scanning calorimetry}

Thermograms of the systems studied were obtained using a Mettler DSC 1 calorimeter (Mettler Toledo, Switzerland). The samples (approx. $20 \mathrm{mg}$ ) were placed into aluminium crucible and sealed. For each sample, no less than four cooling-heating cycles were recorded with scanning rate $2 \mathrm{~K} / \mathrm{min}$. The parameters of the phase transitions were determined using the original Mettler DSC $1 \mathrm{STAR}^{\mathrm{e}}$ software. The experimental error for $T_{m}$ value was $\pm 0.1^{\circ} \mathrm{C}$, for $\Delta H_{m}$ value $- \pm 1.5 \mathrm{~J} / \mathrm{g}$.

\section{Results and Discussion}

Fig. 2 shows the thermograms of model phospholipid membranes on the water/OEG ${ }_{\mathrm{n}=5}$ subphase normalized with respect to the mass of dry DPPC for different cryoprotectant content in the subphase. The thermograms obtained with $\mathrm{OEG}_{\mathrm{n}=25}, \mathrm{OEG}_{\mathrm{n}=30}$ and glycerol in the same conditions are qualitatively similar, though the effect of glycerol upon phase transition peaks of the DPPC membranes is much weaker. In the DPPC-water system (0 \%), two phase transitions are observed in the heating mode: pretransi- 
tion $\left(T_{p}=35.6^{\circ} \mathrm{C}\right)$ from the $L_{\beta}$, gel phase to the intermediate («ripple») phase $P_{\beta}$, and the main phase transition or the membrane melting $\left(T_{m}=41.8^{\circ} \mathrm{C}\right)$ from the $P_{\beta}$, phase to the liquid crystalline $L_{\alpha}$ phase, which is in agreement with the literature data [30, $31]$. For all the $\mathrm{OEG}_{\mathrm{n}}$ used $(n=5,25,30)$, the main transition peak was preserved in all the concentration range up to complete substitution of OEG for water in the $\mathrm{DPPC}+\left[\right.$ water $\left./ \mathrm{OEG}_{\mathrm{n}}\right]$ system. A similar picture was reported for replacing water with glycerol [12], which is also confirmed by our data.

Based on our DSC thermograms and literature data [12], the phase diagram for DPPC membrane on the water/glycerol subphase can be presented (Fig. 3). The effect of glycerol upon $T_{p}$ and $T_{m}$ is rather weak; at glycerol concentration in the subphase above $60 \%$ $\mathrm{w} / \mathrm{w}$ the pretransition peak apparently disappears, and the $T_{m}$ peak enthalpy increases by $\sim 5 \mathrm{~J} / \mathrm{g}$, which can be a marker for formation of the interdigitated gel phase $L_{\beta I}$ [20]; this is confirmed by the X-ray structural data [12].

The phase transition temperatures $T_{p}$ and $T_{m}$ for systems $\mathrm{DPPC}+\left[\right.$ water $\left./ \mathrm{OEG}_{\mathrm{n}=5}\right]$ (a), DPPC $+[$ water/ $\left.\mathrm{OEG}_{\mathrm{n}=25}\right]$ and $\mathrm{DPPC}+\left[\right.$ water $\left./ \mathrm{OEG}_{\mathrm{n}=30}\right]$ (b) are presented in Fig. 4. With higher $\mathrm{OEG}_{\mathrm{n}}$ concentrations, the phase transition temperatures increased. This effect is more marked for $T_{p}$ than for $T_{m}$, which suggests the predominant interaction of the cryoprotectants with the polar region of the membranes. When the $\mathrm{OEG}_{\mathrm{n}}$ fraction in the subphase exceeds $20 \%$, $\mathrm{w} / \mathrm{w}$ the pre-transition peak is getting overlapped with the stronger melting peak. The melting peak becomes smeared at the $\mathrm{OEG}_{\mathrm{n}}$ content above $30 \%$, reflecting weaker cooperativity of the main phase transition; however, it persists on the thermograms up to $\sim 100 \%$ of $\mathrm{OEG}_{\mathrm{n}}$ in the subphase. Two regions can be singled out on the $T_{m} v s$. OEG $\mathrm{n}_{\mathrm{n}}$ concentration dependence. Up to $40 \%$ of the cryoprotectant, $T_{m}$ grows slowly, and above $40 \%$ the $T_{m}$ increase becomes rather noticeable, especially for $\mathrm{OEG}_{\mathrm{n}=25}$ and $\mathrm{OEG}_{\mathrm{n}=30}$. The maximum increase in $T_{m}$ is by $\sim 25^{\circ} \mathrm{C}$ at $\sim 100 \%$ $\mathrm{OEG}_{\mathrm{n}=30^{\circ}}$. It can be assumed that the OEG $\mathrm{n}$ cryoprotectants, similarly to glycerol, lead to interdigitation of the lipid membrane. However, the melting enthalpy $\left(\Delta H_{m}\right)$ data support this assumption only for the
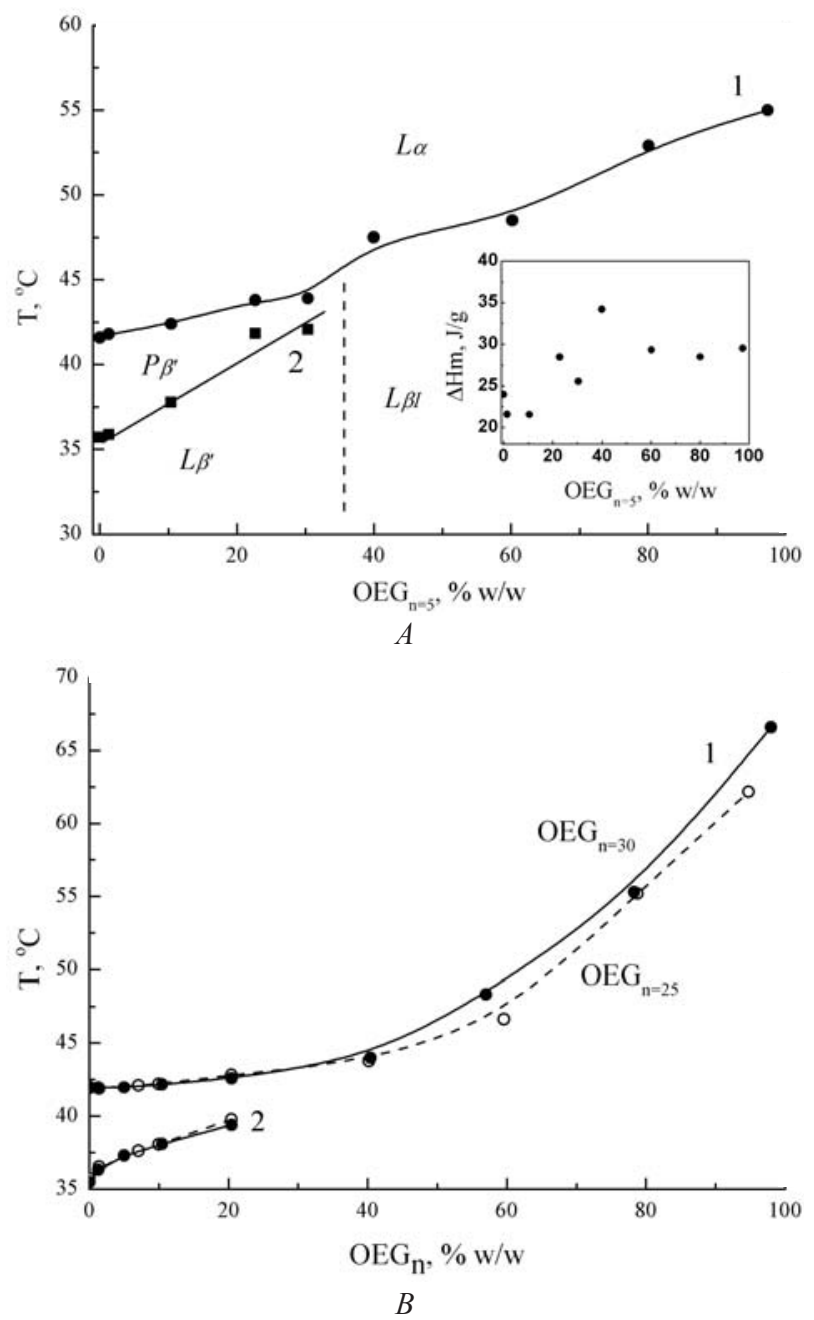

Fig. 4. Temperatures of melting $T_{m}(1)$ and pre-transition $T_{p}(2)$ in systems $\mathrm{DPPC}+\left[\right.$ water $\left./ \mathrm{OEG}_{\mathrm{n}=5}\right](A), \mathrm{DPPC}+\left[\right.$ water $\left./ \mathrm{OEG}_{\mathrm{n}=25}\right]$ and $\mathrm{DPPC}+\left[\right.$ water/OEG $\left.\mathrm{OE}_{\mathrm{n}=30}\right](B)$ as function of $\mathrm{OEG}_{\mathrm{n}}$ content in the subphase. Insert shows the values of melting enthalpy $\Delta H_{m}$

$\mathrm{DPPC}+\left[\right.$ water $/ \mathrm{OEG}_{\mathrm{n}=5}$ ] system: $\Delta H_{m}$ increase is observed when the cryoprotectant content in the subphase increased from 20 to $40 \%$ (Insert, Fig. 4, A). For $\mathrm{DPPC}+\left[\right.$ water $\left./ \mathrm{OEG}_{\mathrm{n}=25}\right]$ and DPPC $+\left[\right.$ water $\left./ \mathrm{OEG}_{\mathrm{n}=30}\right]$, no clear jumps of $\Delta H_{m}$ on the concentration dependence are observed. Further clarification on eventual induction of the interdigitated phases by $\mathrm{OEG}_{n}$ cryoprotectants could probably be obtained by the X-ray structural analysis.

Let us consider in more detail the effects of cryoprotectants on the melting temperature of the phos- 


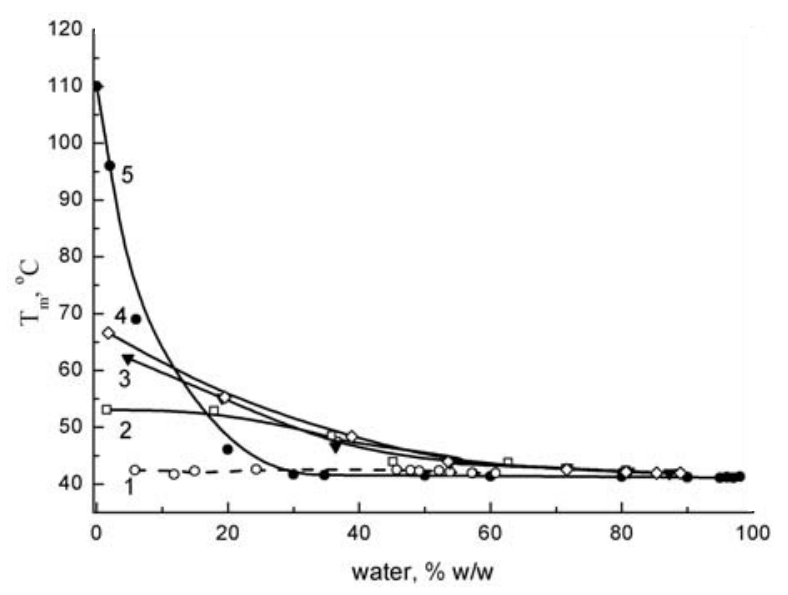

Fig. 5. Melting temperature $T_{m}$ of DPPC membranes as function of water concentration in subphases water/glycerol (1), water/ $\mathrm{OEG}_{\mathrm{n}=5}(2)$, water/OEG ${ }_{\mathrm{n}=25}(3)$, water/OEG $\mathrm{OE}_{\mathrm{n}=30}$ (4) and water (5)
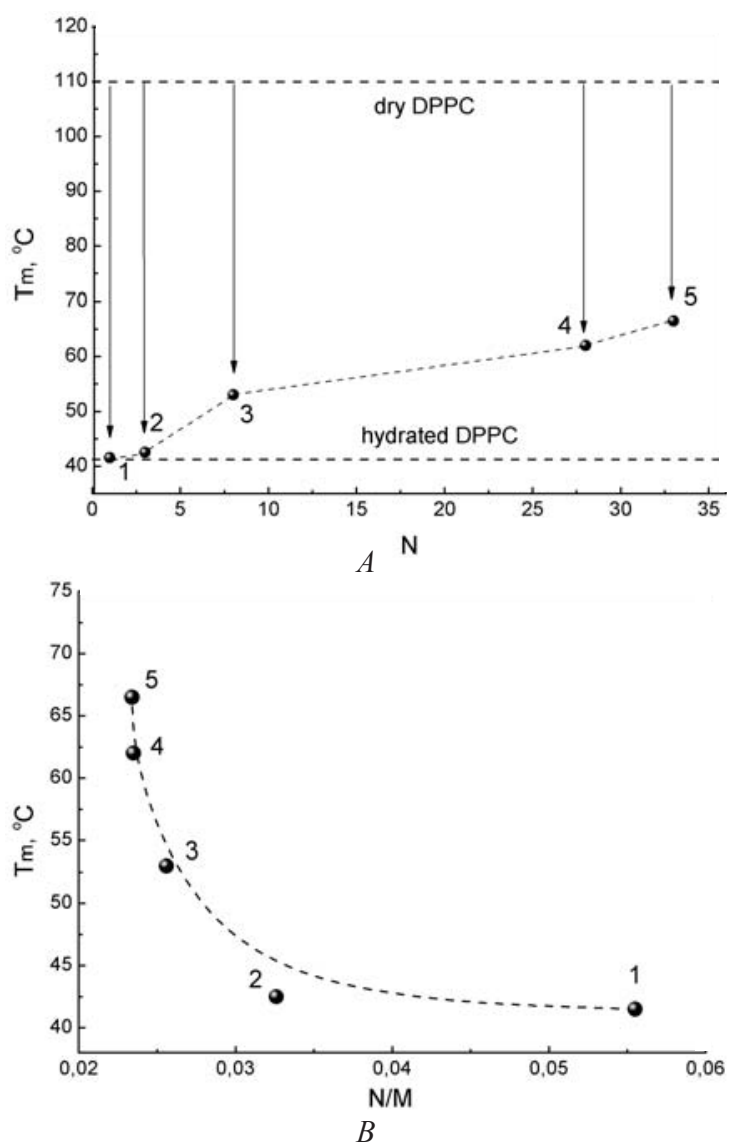

Fig. 6. Melting temperature of DPPC membranes on different subphases as function of the number of polar centers $N(A)$ and relative number of polar centers $N / M(B)$ in the solvating molecule: 1 - water, 2 - glycerol, $3-\mathrm{OEG}_{\mathrm{n}=5}, 4-\mathrm{OEG}_{\mathrm{n}=25}, 5-\mathrm{OEG}_{\mathrm{n}=30}$ pholipid membranes. In Fig. 5 one can see $T_{m}$ as a function of water concentration for ternary systems $\left(\mathrm{DPPC}+\left[\right.\right.$ water/ $\left./ \mathrm{OEG}_{\mathrm{n}=5}\right], \mathrm{DPPC}+\left[\right.$ water $\left._{\mathrm{O}} / \mathrm{OEG}_{\mathrm{n}=25}\right] \mathrm{DPPC}+$ [water/OEG $\left.{ }_{\mathrm{n}=30}\right]$ and $\mathrm{DPPC}+[$ water/glycerol]). For comparison, the data for the binary system DPPC+water (without cryoprotectant) are also presented.

From the data of Fig. 5, it can be concluded that the effects of cryoprotectants on the melting temperature of lipid membranes can be considered in two aspects: 1) an increase in $T_{m}$ when water is replaced by the cryoprotectant, and 2) lowering $T_{m}$ due to solvation of the dry lipid by the cryoprotectant. Let us consider this in more details.

It is known that in the binary system DPPC+water the value of $T_{m}$ for the fully hydrated DPPC is practically constant $[18,30]$. With continuous dehydration, when the water content becomes less than $\sim 30 \%$ (which corresponds to 18 water molecules per one molecule of DPPC), $T_{m}$ noticeably increased, reaching $\sim 110^{\circ} \mathrm{C}$ for dry DPPC [18] (Fig. 5). This can be explained by stronger Van-der-Waals interactions between the hydrocarbon «tails» due to a decrease in the cross-section area of polar lipid «heads» [19]. In the ternary systems, when water is replaced by cryoprotectant, the melting temperature increases, assuming the values between $T_{m}$ of hydrated DPPC and $T_{m}$ of dry DPPC (Fig. 6, $A$ ). The $T_{m}$ increase is rather small when the $\mathrm{OEG}_{\mathrm{n}}$ concentration is still below $\sim 40 \% \mathrm{w} / \mathrm{w}$. One can assume that in this concentration region there is enough water in the system for hydration of both the lipid and $\mathrm{OEG}_{\mathrm{n}}$. When the cryoprotectant content is further increased, the available water is not sufficient for hydration of the polar region of the lipid membrane and the $\mathrm{OEG}_{\mathrm{n}}$ molecules, and solvation of the membrane by the cryoprotectant molecules begins to play an important role. Thus, with further dehydration of the system, $T_{m}$ increases, not reaching, however, the values noted for the dry DPPC because of solvation of the polar region of the DPPC membrane by the $\mathrm{OEG}_{\mathrm{n}}$ molecules (Fig. 6, $A$ ).

Accounting for [16-19], it can be concluded that the lowering of $T_{m}$ of the dehydrated lipid due to its solvation by the cryoprotectant is of an obvious biophysical significance. One may assume that this value reflects the solvating ability of the subphase with 
respect to the lipid membrane. The obtained experimental data show that at a higher polymerization degree $n$ of the cryoprotectant the decrease in $T_{m}$ becomes less pronounced, i.e., the solvation ability of $\mathrm{OEG}_{\mathrm{n}}$ decreases with the increase in $n$. Taking water as the reference, the solvation ability of the subphase decreases in the series: water $>$ glycerol $>\mathrm{OEG}_{\mathrm{n}=5}>$ $\mathrm{OEG}_{\mathrm{n}=25}>\mathrm{OEG}_{\mathrm{n}=30}$.

In this series the number of polar groups $N$ per one molecule increases (Fig. 6, $A$ ), but the number of polar groups normalized with respect to the molecular mass $M(N / M)$ decreases (Fig. 6, B). In the $\mathrm{OEG}_{\mathrm{n}}$ molecules two kinds of polar centers can be distinguished that can interact with the polar region of the membrane (and with water) - hydroxyl groups $(-\mathrm{OH})$ and ethoxy groups $\left(-\mathrm{CH}_{2}-\mathrm{CH}_{2}-\mathrm{O}-\right)$. With a higher $n$, the relative number of ethoxy groups is larger, and that of hydroxyl groups is smaller. It should be noted that only hydroxyl groups are present in water and glycerol molecules; the solvating abilities of water and glycerol (estimated by $T_{m}$ depression of dry DPPC) are close to one another and are much higher as compared with $\mathrm{OEG}_{\mathrm{n}}$. In other words, the hydroxyl groups are more efficient as solvating agents for DPPC membrane than the ethoxy groups.

This statement can be supported by following speculations. In zwitterionic DPPC molecules there are two charged centers, namely, negatively charged oxygen atoms in phosphate groups and positively charged nitrogen in choline groups. Unlike negative charge of oxygens, the nitrogen positive charge is screened by three methyl groups. So, the membrane solvation process is essentially determined by interaction between negatively charged DPPC phosphate groups and atoms with sufficient positive charge from the subphase molecules. This positive charge is located on hydrogen of the hydroxyl groups, which can explain their higher solvating ability as compared with ethoxy groups.

Returning to Fig. 6, $B$, the non-linear plot describing the solvating ability of subphase is a multi-parameter function, depending on both quantity and quality of polar centers in subphase molecules. Indeed, for $\mathrm{OEG}_{\mathrm{n}}$ ( points 3 to 5 in Fig. 6, B) the Tm values dramatically increase, whereas the relative number of polar centers is slightly diminishing.
Additionally, with a higher molecular mass of the cryoprotectant the probability of efficient interaction of all its polar groups with the polar groups of the lipid molecules decreases due to steric factors.

Thus, the decrease in the solvating ability of the subphase for DPPC membranes is in the following order: water $>$ glycerol $>\mathrm{OEG}_{\mathrm{n}=5}>\mathrm{OEG}_{\mathrm{n}=25}>\mathrm{OEG}_{\mathrm{n}=30}$. This can be explained by the lowering of the relative number of hydroxyl groups that effectively contribute to the solvation process.

\section{Conclusions}

For the first time, the DPPC model membranes on the water/oxyethylated glycerols $\left(\mathrm{OEG}_{\mathrm{n}}\right)$ subphase with varying $\mathrm{OEG}_{\mathrm{n}}$ concentrations from 0 to $\sim 100 \%$ were studied by DSC method. It has been shown that the $\mathrm{OEG}_{n}$ cryoprotectants substitute for water, with a substantial increase in the pre-transition and melting temperatures of the model membranes. The melting peak was clearly observed up to $\sim 100 \% \mathrm{OEG}_{\mathrm{n}}$. With $\mathrm{OEG}_{\mathrm{n}}$ substituting for water, the melting temperatures of DPPC membranes were lower as compared with dry DPPC. The cryoprotectant concentration range was determined $(20-40 \% \mathrm{w} / \mathrm{w})$ where the melting enthalpy of the DPPC membrane on the water/OEG $\mathrm{O}_{\mathrm{n} 5}$ subphase sharply increased. The solvating ability of the subphase with respect to DPPC membranes decreases in the following order water $>$ glycerol $>\mathrm{OEG}_{\mathrm{n}=5}>\mathrm{OEG}_{\mathrm{n}=25}>\mathrm{OEG}_{\mathrm{n}=30}$, which correlates with the relative number of the groups effectively contributing to the solvation process.

\section{REFERENCES}

1. Pignatello R, Musumeci T, Basile L, Carbone C, Puglisi G. Biomembrane models and drug-biomembrane interaction studies: Involvement in drug design and development. J Pharm Bioallied Sci. 2011;3(1):4-14.

2. Peetla $C$, Stine A, Labhasetwar $V$. Biophysical interactions with model lipid membranes: applications in drug discovery and drug delivery. Mol Pharm. 2009;6(5):1264-76.

3. Seydel JK, Wiese M. Drug-membrane interactions: analysis, drug distribution, modeling. Wiley-VCH Verlag $\mathrm{GmbH}$, Weinheim, 2002, $349 \mathrm{p}$

4. Nardid $O$. Study of low-molecular effect of cryoprotectants on mitochondria respiratory chain by spin probe EPR. Prob- 
lems of Cryobiology. 2009; 19(2):177-85.

5. Anchordoguy T, Rudolph A, Carpenter J, Crowe J. Modes of interaction of cryoprotectants with membrane phospholipids during freezing. Cryobiology. 1987; 24(4): 324-31.

6. Kiselev M, Lesieur P, Kisselev A, Ollivon M. Ice formation in model biological membranes in the presence of cryoprotectants. Nuclear Instruments \& Methods in Physics Research A. 2000; 448(1-2): 225-60.

7. Korniyenko YeM, Posokhov YeO, Localization of penetrating cryoprotectant dimethylsulfoxide in red cell membranes: a study by fluorescent probes. The Journal of $V$. N. Karazin Kharkiv National University. Ser: Biol. 2011; 14(971) :135-9.

8. Notman R, Noro M, O'Malley B, Anwar J. Molecular basis for dimethylsulfoxide (DMSO) action on lipid membranes. $J$ Am Chem Soc. 2006;128(43):13982-3.

9. Gurtovenko AA, Anwar J. Modulating the structure and properties of cell membranes: the molecular mechanism of action of dimethyl sulfoxide. $J$ Phys Chem $B$. 2007;111(35):10453-60.

10. Gorshkova YuE, Ivankov OI, Kuklin AI, Gordeliy VI. Investigation of DESO/LIPID membranes interaction by X-Ray scattering. J Phys: Conf Ser. 2012; 351:012006.

11. Westh P. Unilamellar DMPC vesicles in aqueous glycerol: preferential interactions and thermochemistry. Biophys $J$. 2003;84(1):341-9.

12. McDaniel RV, McIntosh TJ, Simon SA. Nonelectrolyte substitution for water in phosphatidylcholine bilayers. Biochim Biophys Acta. 1983; 731(1):97-108.

13. Konov KB, Isaev NP, Dzubab SA. Glycerol penetration profile in phospholipid bilayers measured by ESEEM of spinlabelled lipids. Molecular Physics. 2013;111(18-19): 2882-6

14. Szmant HH. Physical properties of dimethyl sulfoxide and its function in biological systems. Ann NY Acad Sci. 1975;243:20-3.

15. Nowacka A, Douezan S, Wads L, Topgaard D, Sparr E. Small polar molecules like glycerol and urea can preserve the fluidity of lipid bilayers under dry conditions. Soft Matter. 2012; 8: 1482-91.

16. Crowe JH, Crowe LM, Chapman D. Preservation of membranes in anhydrobiotic organisms: the role of trehalose. Science. 1984;223(4637):701-3

17. Oliver AE, Crowe LM, Crowe JH. Methods for dehydrationtolerance: depression of the phase transition temperature in dry membranes and carbohydrate vitrification. Seed Sci. Res. 1998;8(2):211-21.

18. Crowe JH, Crowe LM, Hoekstra FA. Phase transitions and permeability changes in dry membranes during rehydration.
J Bioenerg Biomembr. 1989;21(1):77-91.

19. Crowe LM, Crowe JH, Chapman D. Interaction of carbohydrates with dry dipalmitoylphosphatidylcholine. Arch Biochem Biophys. 1985;236(1):289-96.

20. Mavromoustakos T, Chatzigeorgiou P, Koukoulitsa C, Durdagi S. Partial interdigitation of lipid bilayers. Int J Quantum Chem. 2011; 111(6):1172-83.

21. Veiro JA, Nambi P, Herold LL, Rowe ES. Effect of n-alcohols and glycerol on the pretransition of dipalmitoylphosphatidylcholine. Biochim Biophys Acta. 1987;900(2): 230-8.

22. Swamy MJ, Marsh D. Thermodynamics of interdigitated phases of phosphatidylcholine in glycerol. Biophys $J$. 1995;69(4):14025-8.

23. O'Leary TJ, Levin IW. Raman spectroscopic study of an interdigitated lipid bilayer dipalmitoylphosphatidylcholine dispersed in glycerol. Biochim Biophys Acta. 1984; 776(2):185-9.

24. Zhivotova EN, Zinchenko AV, Kuleshova LG, Chekanova $V V$, Kompaniets $A M$. Physical states of aqueous solutions of oxyethylated glycerol with polymerization degree of $\mathrm{n}=30$ at temperatures lower than $283 \mathrm{~K}$. Cryo Letters. 2007;28(4):261-70.

25. Dashnau JL, Nucci NV, Sharp KA, Vanderkooi JM. Hydrogen bonding and the cryoprotective properties of glycerol/ water mixtures. $J$ Phys Chem B. 2006;110(27):13670-7.

26. Lubyanyi V, Bredikhina L, Shrago M. Cryoprotective activity of OEG oligomers in the red cell low temperature preservation. Kriobiologiya. 1981; 8:34-40.

27. Pakhomova YS, Chekanova VV, Kompaniets AM. Cryoprotective properties of solutions based on non-penetrative $\mathrm{OEGn}=25$ combined with penetrating cryoprotectants during freezing of human erythrocytes. Problems of Cryobiology and Cryomedicine. 2013; 23(1):26-39.

28. Shrago MI, Guchok MM, Kalugin YuV. Some principles of direct synthesis of cryoprotectants. In: Current Problems of Cryobiology. Eds. Pushkar NS and Belous AM. Kiev: Naukova Dumka, 1981:157-201.

29. Kompaniets AM, Chekanova VV, Nikolenko AV, Zinchenko $A V$, Pakhomova YS. Synthesis, physico-chemical and cryoprotectant properties of oxyethyl derivatives of alcohols. In: Actual problems of cryobiology and cryomedicine. Ed. Acad. Gol'tsev AN. Kharkov: Raider, 2012:73-100

30. Ivkov VG, Berestovskiy GN. Dynamic structure of lipid bilayer. Moscow: Nauka, 1981. 296 p.

31. Wack $D C, W e b b W W$. Synchrotron x-ray study of the lamellar phase $\mathrm{P} \beta$ ' in the lecithin-water system. Phys Rev A. 1989; 40(5):2712-30. 
Влияние криопротекторов группы оскиэтилированных производных глицерина на фазовые переходы модельных мембран на основе ДПФХ

Н. А. Касян, А. О. Красникова, О. В. Ващенко, Л. Н. Лисецкий, А. В. Зинченко,

А. М. Компаниец, М. В. Ратушная

Цель. Установление влияния криопротекторов группы оксиэтилированных производных глицерина (ОЭГ $)$ со степенями полимеризации $\mathrm{n}=5,25$ и 30 на фазовые состояния и фазовые переходы модельных липидных мембран на основе ДПФХ. Методы. Дифференциальная сканирующая калориметрия. Результаты. Исследованы модельные липидные мембраны на субфазе вода/ОЭГ и вода/глицерин с варьированием концентрации криопротектора от 0 до $\sim 100$ масс. \%. С увеличением концетрации ОЭГ существенно возрастают температуры предперехода и плавления модельной мембраны, при этом пик плавления сохраняется вплоть до 100 масс. \% ОЭГ . Для ОЭГ обнаружено значительное возрастание энтальпии плавления мембраны. Выводы. Сольватирующая способность субфазы, оцененная по снижению температуры плавления сухого ДПФХ, снижается в ряду вода $>$ глицерин $>$ ОЭГ ${ }_{\mathrm{n}=5}>\mathrm{O}_{\mathrm{n}=25}>$ $>$ ОЭГ ${ }_{\mathrm{n}=30}$, что коррелирует с уменьшением удельного количества эффективно участвующих в сольватации групп.

Ключев ы е сл о а: модельне липидные мембраны, оксиэтилированные производные глицерина, фазовые переходы, сольватация
Вплив кріопротекторів групи оксиетильованих похідних гліцерину на фазові переходи модельних мембран на основі ДПФХ

Н. О. Касян, А. О. Краснікова, О. В. Ващенко, Л. М. Лисецький, О. В. Зінченко,

А. М. Компанієць, М. В. Ратушна

Мета. Встановлення впливу кріопротекторів групи оксиетильованих похідних гліцерину $\left(\mathrm{OE} \Gamma_{\mathrm{n}}\right)$ зі ступенями полімеризації $\mathrm{n}=5,25$ и 30 на фазові стани та фазові переходи модельних ліпідних мембран на основі ДПФХ. Методи. Диференціальна скануюча калориметрія. Результати. Досліджено модельні ліпідні мембрани на субфазі вода/ОЕГ та вода/гліцерин із варіюванням концентрації кріопротектору від 0 до 100 мас. \%. Зі збільшенням концентрації ОЕГ суттєво зростають температури передпереходу та плавлення модельної мембрани, при цьому пік плавлення зберігається до 100 мас. \% ОЕГ . Для ОЕГ $_{n=5}$ віднайдено значне зростання ентальпії плавлення мембрани. Висновки. Сольватуюча здатність субфази, що оцінена по зниженню температури плавлення сухого ДПФХ, знижується у низці вода $>$ гліцерин $>\mathrm{OE} \Gamma_{\mathrm{n}=5}>\mathrm{OE} \Gamma_{\mathrm{n}=25}>\mathrm{OE} \Gamma_{\mathrm{n}=30}$, що корелює зі зменшенням питомої кількості груп, що ефективно беруть участь у сольватації.

К л юч о в і с л о в а: модельні ліпідні мембрани, оксиетильовані похідні гліцерину, фазові переходи, сольватація.

Received 26.11.2014 